\title{
ANALISIS KESALAHAN BERBAHASA DALAM TAKSONOMI \\ KATEGORI LINGUISTIK PADA PENYUSUNAN TEKS \\ BIOGRAFI SISWA KELAS X SMA NEGERI 7 MEDAN \\ TAHUN PEMBELAJARAN 2017/2018
}

\author{
Oleh \\ Rolina Santi Harianja (rolina.santi@gmail.com) \\ Trisnawati Hutagalung, S.Pd., M.Pd.
}

\begin{abstract}
ABSTRAK
Penelitian ini dilakukan di SMA Negeri 7 Medan pada semester ganjil tahun pembelajaran 2017/2018. Penelitian ini bertujuan untuk : 1) untuk mengetahui kesalahan penggunaan morfologi yang berupa afiksasi dan kata ulang, 2) untuk mengetahui kesalahan penggunaan sintaksis yang berupa frasa, 3) untuk mengetahui kesalahan penggunaan leksikon yang berupa kata yang tidak atau kurang tepat. Pengambilan sample dilakukan secara random sampling, maka ditetapkan sebanyak 35 siswa yang menjadi subjek penelitian. Penelitian ini merupkan penelitian deskriptif kualitatif. Penelitian ini menggunakan teks siswa kelas $\mathrm{X}$ SMA Negeri 7 Medan sebagai sumber data, yang dipilih sebanyak 35 teks. Adapun objek penelitiannya adalah kesalahan Berbahasa dalam Taksonomi Kategori Linguistik. Data diperoleh dengan teknik dokumentasi. Metode analisisnya menggunakan metode analisis deskriptif kualitatif. Instrumen yang digunakan pada penelitian ini adalah human instrument. Teknik pengumpulan data dalam penelitian ini adalah dengan menggunakan teknik analisis dokumen. Teknik ini dilakukan dengan tujuan untuk mengumpulkan data yang bersumber dari dokumen. Hasil penelitian ini menunjukkan bahwa total kesalahan berbahasa dalam taksonomi kategori linguistik. Jumlah keseluruhan kalimat yang mengandung kesalahan berbahasa dalam taksonomi linguistik dari 35 teks siswa adalah sebanyak 139 kalimat dengan perincian 87 kalimat $(62,58 \%)$ mengandung kesalahan penggunaan morfologi (terdapat 78 kesalahan afiksasi dan 8 kesalahan menggunakan kata ulang). Sementara kesalahan frasa pada sintaksis terdapat dalam 37 kalimat (26,61\%). Selanjutnya terdapat sebanyak 15 kalimat $(10,79 \%)$ yang mengandung kesalahan leksikon.
\end{abstract}

\section{Kata Kunci: Kesalahan Berbahasa, Taksonomi Kategori Linguistik, Teks Biografi}

\section{PENDAHULUAN}

Bahasa erat kaitannya dengan kehidupan manusia, pada kenyataannya bahasa adalah keseharian manusia. Bahasa muncul dan diperlukan dalam segala 
kegiatan seperti pada bidang pendidikan, keagamaan, bidang perdagangan, bidang politik, bidang militer, bidang kebudayaan, bidang sosial dan lain-lain.

Pada bidang pendidikan siswa dan mahasiswa dituntut untuk bisa menggunakan bahasa Indonesia dengan baik dan benar dalam mengkomunikasikan ilmunya. Penentuan atau kriteria berbahasa Indonesia yang baik dan benar itu tidak jauh berbeda dengan yang dikatakan sebagai berbahasa baku. Kebakuan suatu bahasa sudah menunjukkan masalah "baik" dan "benar" bahasa itu. Yang paling berperan dalam kegiatan berbahasa adalah orang yang menggunakan bahasa tersebut (Setyawati, 2013 : 9)

Pemilihan kata dalam berbahasa adalah proses pembentukan kalimat atau kata-kata yang disusun dalam sebuah wacana supaya dapat digunakan untuk menyampaikan amanat atau pesan kepada pembaca atau lawan bicara. Sangat penting menghindari atau mengurangi kesalahan dalam berbahasa, sehingga amanat atau pesan yang kita sampaikan itu dapat diterima dengan baik dan sesuai dengan konsep yang kita inginkan. Akan tetapi sering sekali kita masih menemukan kesalahan-kesalahan berbahasa. Seperti pada bidang pendidikan, kesalahan berbahasa juga terjadi dan terdapat dalam pengajaran berbahasa.

Tarigan (1988: 67) menuliskan dalam bukunya yang berjudul Pengajaran Analisis Kesalahan Berbahasa, Pengalaman para guru bahasa dilapangan membuktikan bahwa kesalahan berbahasa yang dibuat oleh siswa sering sekali diluar dugaan. Artinya, kesalahan itu ada yang sesuai dengan perkiraan tetapi banyak juga dari luar perkiraan guru.

Kesalahan berbahasa yang dilakukan oleh siswa dalam proses belajar mengajar mengimplikasikan tujuan pengajaran bahasa belum tercapai secara maksimal. Semakin tinggi kuantitas kesalahan berbahasa itu, semakin sedikit tujuan pengajaran bahasa yang tercapai. Kesalahan berbahasa yang dilakukan oleh siswa harus dikurangi sampai ke batas minimal, bahkan diusahakan dihilangkan sama sekali. Hal ini dapat tercapai jika guru pengajar bahasa telah mengkaji secara mendalam segala aspek seluk-beluk kesalahan berbahasa itu.

Tarigan (1988: 139) memaparkan, ada empat taksonomi kesalahan berbahasa yang penting untuk kita ketahui: (a) taksonomi kategori linguistik; (b) 
taksonomi siasat permukaan; (c) taksonomi komparatif; (d) taksonomi efek komunikatif.

Kesalahan berbahasa tidak hanya terdapat pada tuturan tetapi juga terdapat pada bahasa tertulis. Hal ini ditinjau dari ragam bahasa berdasarkan sarana pemakaiannya. Dilihat dari segi sarana pemakaiannya, ragam bahasa dapat dibedakan atas ragam lisan dan tulis (Setyawati $2013: 2$ ).

Menurut Nurgiantoro (dalam Samsuri 1982:130) bahwa dibanding dengan keterampilan menyimak, membaca, dan berbicara, keterampilan menulis merupakan keterampilan yang paling rendah penguasaannya. Sejalan dengan pernyataan di atas, rendahnya penguasaan keterampilan menulis didalamnya juga termasuk rendahnya kemampuan siswa dalam menulis teks biografi. Teks biografi merupakan suatu kisah atau keterangan tentang kehidupan seseorang yang bersumber pada subjek rekaan (nonfiction) atau kisah nyata. Sebuah biografi lebih kompleks dari sekedar biodata seseorang, karena dalam biografi juga menceritakan pengalaman, masalah, perasaan, maupun kenangan yang terjadi dalam kehidupan seseorang yang dapat menggambarkan kepribadian atau watak dari seseorang yang diceritakan dalam biografi tersebut. Pernyataan di atas, didukung oleh Dewi (2013:7) yang menyatakan, teks biografi adalah teks yang berisi tentang riwayat hidup seorang tokoh dalam menjalani kehidupannya. Perjalanan hidup tokoh ini dapat memuat hal-hal yang menarik sehingga bisa diteladani oleh siswa.

Peneliti melakukan wawancara dengan guru bidang studi Bahasa Indonesia di SMA Negeri 7 Medan, Bapak M. Hanafiah Lubis, S.Pd dan ibu Aidah Rizkina, S.Pd. Hasil wawancara tersebut menunjukkan kemampuan menulis teks biografi siswa masih terdapat kesalahan-kesalahan berbahasa. Kesalahan paling sering terjadi pada morfologi, siswa masih bingung dalam memilih afiks, dan penggunaan kata ulang. Begitu juga dengan kesalahan-kesalahan sintaksis dan leksikon, siswa masih sering salah dalam penulisan frasa dan serta menggunakan kata yang belum tepat. Kesimpulan tersebut berdasar pada hasil penugasan maupun ujian siswa. 
Kesalahan berbahasa dalam bidang morfologi ini didukung dengan adanya penelitian Harsanti Magasari (2014) Analisis Kesalahan Berbahasa dalam bidang morfologi pada karangan Siswa Kelas VII G SMP Negeri 1 Godong. Hasil penelitian ini menunjukkan kesalahan kata pada penulisan prefiks ter- , penulisan prefiks ber-, kesalahan penulisan kata depan (di dan ke), kesalahan prefiks di-, kesalahan penulisan gabungan sufiks - kan, kesalahan bentuk afiks di- dan ke-.

Sementara Kesalahan berbahasa dalam bidang sintaksis didukung dengan adanya penelitian penelitian yang dilakukan Nurul Isitinganah (2012) Analisis Kesalahan Sintaksis Pada Karangan Narasi Ekspositoris Siswa Kelas VIII SMP Negeri 1 Banguntapan Bantul Yogyakarta. Hasil penelitian ini menunjukkan jumlah kalimat yang mengandung kesalahan sintaksis tersebut terdiri dari kesalahan penggunaan struktur frasa sebanyak 95 kalimat $(30,94 \%)$ dan kesalahan penggunaan struktur kalimat sebanyak 196 kalimat (63,84\%).

Sejalan juga dengan penelitian yang dilakukan Ira Wibowo (2016) Analisis Kesalahan Ejaan dan Kalimat dalam Teks Cerita Pendek Karya Siswa Kelas IX SMP Kanisius Kalasan Sleman Tahun Ajaran 2015/2016. Jumlah kesalahan ejaan yang ditemukan sebanyak 597 kesalahan dan kesalahan kalimat sebanyak 155 kesalahan.

Berdasarkan pemaparan latar belakang di atas, penulis tertarik untuk meneliti masalah yang ada di dalamnya dalam bentuk karya tulis ilmiah berupa skripsi yang berjudul "Analisis Kesalahan Berbahasa dalam Taksonomi Kategori Linguistik pada Penyusunan Teks Biografi Siswa Kelas X SMA Negeri 7 Medan Tahun Pembelajaran 2017/2018."

\section{METODE PENELITIAN}

Metode penelitian adalah suatu cara dalam proses pemecahan masalah dengan mengumpulkan dan menganalisis data untuk mencapai tujuan yang digunakan. Metode penelitian adalah cara yang digunakan oleh peneliti dalam mengumpulkan data penelitiannya (Arikunto, 2013:203). Metode Penelitian merupakan hal yang penting untuk diperhatikan dalam sebuah penelitian. Hal ini disebabkan segala kegiatan yang dilakukan dalam sebuah penelitian dalam upaya 
menemukan dan membuktikan sesuatu sepenuhnya tergantung pada metode yang digunakan.

Penelitian ini menggunakan pendekatan kualitatif . (Iskandar, 2009: 11) menyatakan bahwa, "Pendekatan kualitatif adalah suatu proses penelitian dan pemahaman yang berdasarkan pada metodologi yang menyelidiki suatu fenomena sosial dan masalah manusia”. Putra (2013:45), menyatakan, penelitian kualitatif merumuskan masalah secara induktif, berdasarkan data di lapangan. Konsekuensinya, penelitian kulaitatif tidak berkutat dengan variabel dan teori.”

\section{HASIL DAN PEMBAHASAN PENELITIAN}

\section{Hasil Penelitian}

\section{Kesalahan penggunaan morfologi pada penyusunan teks biografi siswa kelas X SMA Negeri 7 Medan}

Setelah dilakukan penelitian, diperoleh kesalahan berbahasa dalam taksonomi kategori linguistik. Terdapat 87 kalimat (62,58\%) mengandung kesalahan penggunaan morfologi, diantaranya : 28 kesalahan menentukan bentuk asal; 1 kesalahan pada fonem yang tidak luluh diluluhkan; 1 kesalahan pada penyingkatan morf men-, meny-, meng-, dan menge-, menjadi $n, n y, n g$, dan $n g e ; 1$ kesalahan pada perubahan morfem ber-, per-, dan ter- menjadi be-, pe-, dan te-; 19 kesalahan pada penulisan morfem yang salah; 24 kesalahan pada morfem $d i$, $k e$, dan dari yang dikenal dengan kata depan ditulis terpisah dengan kata yang mengikutinya; 2 kesalahan pada morfem pun bermakna juga maka partikel pun dituliskan secara terpisah dengan kata yang diikutinya; 2 kesalahan pada morfem pun tidak bermakna juga maka partikel pun dituliskan serangkai dengan kata yang diikutinya; 9 kesalahan pada salah menggunakan kata ulang.

\section{Kesalahan penggunaan sintaksis pada penyusunan teks biografi siswa kelas X SMA Negeri 7 Medan}

Setelah dilakukan penelitian, diperoleh kesalahan berbahasa dalam taksonomi kategori linguistik. Terdapat 37 kalimat $(26,61 \%)$ mengandung kesalahan pada sintaksis. Kesalahan penggunaan sintaksis berupa frasa pada teks biografi siswa kelas X SMA Negeri 7 Medan dibagi menjadi 11 (sebelas) yaitu (1) 
Pengaruh Bahasa Ibu tidak terdapat kesalahan; (2) Frasa Berkata Depan Tidak Tepat terdapat 2 kesalahan; (3) Salah Susunan terdapat 2 kesalahan, (4) Salah karena Berlebihan terdapat 7 kesalahan; (5) Penambahan Kata dari atau tentang dalam Frasa Nominal $(\mathrm{N}+\mathrm{N})$ terdapat 7 kesalahan; (6) Penambahan Kata untuk atau yang dalam Frasa Nominal (N+V) terdapat 8 kesalahan; (7) Penambahan kata dari, pada atau daripada dalam Frasa Verbal $(\mathrm{V}+\mathrm{N})$ terdapat 2 kesalahan; (8) Penambahan kata untuk dalam Frasa Verbal $\left(\mathrm{V}_{\text {pasif }}+\mathrm{V}_{\text {lain }}\right)$ terdapat 1 kesalahan; (9) Penghilang kata Yang dalam Frasa Nominal (N+yang+A) terdapat 4 kesalahan; (10) Penghilang kata Yang dalam Frasa Nominal $\left(\mathrm{N}+\mathrm{yang}+\mathrm{V}_{\text {pasif }}\right)$ terdapat 2 kesalahan; (11) Penghilang kata Oleh dalam Frasa Verbal Pasif $\left(\mathrm{V}_{\text {pasif }}+\mathrm{Oleh}+\mathrm{N}\right)$ terdapat 2 kesalahan.

\section{Kesalahan penggunaan leksikon pada penyusunan teks biografi siswa kelas X SMA Negeri 7 Medan}

Setelah dilakukan penelitian, diperoleh kesalahan berbahasa dalam taksonomi kategori linguistik. Terdapat sebanyak 15 kalimat (10,79\%) yang mengandung kesalahan leksikon.

Hal tersebut diperoleh berdasarkan penyeleksian data yang telah dilakukan sebagai bagian dari proses analisis dengan membaca cermat dan berulang-ulang. Persentase data diambil berdasarkan jumlah temuan dibagi jumlah keseluruhan kesalahan penggunaan berbahasa dalam taksonomi linguistik dalam teks biografi siswa kemudian dikalikan $100 \%$. Berdasarkan persentase tersebut dapat disimpulkan bahwa kesalahan berbahasa dalam taksonomi kategori linguistik pada teks biografi siswa kelas X SMA Negeri 7 Medan cukup beragam.

Pendeskripisian jenis kesalahan berbahasa dalam taksonomi linguistik yang ditemukan dapat dilihat dalam tabel distribusi frekuensi kesalahan berbahasa dalam taksonomi linguistik berdasarkan bentuk dan faktor-faktor penyebab berikut ini. 
Tabel 4.21 Tabel Distribusi Frekuensi Kesalahan Berbahasa dalam Taksonomi Kategori Linguistik Berdasarkan Bentuk Faktor-Faktor Penyebabnya

\begin{tabular}{|c|l|c|c|}
\hline No. & Bentuk Kesalahan & Data Kesalahan & Jumlah \\
\hline 1. & \multicolumn{1}{|c|}{$\begin{array}{c}\text { Kesalahan } \\
\text { Morfologi }\end{array}$} & Kesalahan penggunaan afiks & 78 \\
\cline { 3 - 4 } 2. & Kesalahan Sintaksis & Penyimpangan frasa & 37 \\
\hline 3. & Kesalahan Leksikon & $\begin{array}{c}\text { Kesalahan memakai kata yang } \\
\text { tidak atau kurang tepat }\end{array}$ & 15 \\
\hline & $\begin{array}{l}\text { Jumlah } \\
\text { Persentase }\end{array}$ & & 139 \\
\hline
\end{tabular}

\section{Pembahasan Hasil Penelitian}

1. Kesalahan penggunaan morfologi pada penyusunan teks biografi siswa kelas X SMA Negeri 7 Medan

Dari hasil analisis yang telah dipaparkan di atas dapat diketahui bahwa lebih banyak jumlah kesalahan morfologi yang disebabkan oleh kesalahan afiksasi. Artinya kemampuan siswa dalam penggunaan afiksasi masih rendah. Siswa masih belum memahami dengan benar penggunaan afiks yang sesuai dan benar. Hal ini sejalan dengan hasil penelitian dalam bentuk E-journal oleh Mistrio Oktaviandy (2015:9), dari hasil penelitian yang telah terkumpul dan diperiksa rata-rata siswa banyak melakukan kesalahan afiksasi yaitu kesalahan penulisan prefiks 35 kesalahan, sufiks 21 kesalahan, dan konfiks 78 kesalahan.

\section{Kesalahan penggunaan sintaksis pada penyusunan teks biografi siswa}

\section{kelas X SMA Negeri 7 Medan}

Siswa menuliskan teks biografi dengan tokoh-tokoh yang berbeda, dan diberikan kebebasan kepada siswa untuk memilih tokoh yang ingin dituliskan biografinya. Hal ini berguna supaya siswa dapat dengan mudah memilih tokoh kesukaan mereka. Kesukaan siswa terhadap tokoh yang akan dipilih tentu berpengaruh dengan pengetahuan siswa mengenai tokoh tersebut. Akan tetapi meskipun diberlakukan hal seperti itu masih terdapat banyak kesalahan yang dilakukan oleh siswa. Setelah kesalahan morfologi terdapat kesalahan sintaksis 
yang memiliki kesalahan terbanyak. Dari antara kesalahan-kesalahan yang terjadi pada kesalahan sintaksis kesalahan penambahan kata untuk atau yang dalam frasa nominal $(\mathrm{n}+\mathrm{v})$ adalah kesalahan terbanyak, terdapat 8 kesalahan. Siswa masih perlu dibekali dengan pengetahuan sistem linguistik untuk mengurangi terjadinya kesalahan-kesalahan berbahasa.

Hal tersebut sesuai dengan yang dipaparkan oleh Tarigan dan Sulistyaningsih (1996:30), kesalahan berbahasa disebabkan oleh faktor pemahaman, kemampuan atau kompetensi. Apabila siswa belum memahami sistem linguistik bahasa yang sedang dipelajari oleh siswa maka yang bersangkutan sering membuat kesalahan tatkala menggunakan bahasa tersebut. Kesalahan ini akan selalu berulang terjadi secara sistematis dan konsisten. Hal ini berlaku secara umum, artinya, terjadi pada setiap siswa. Kesalahan berbahasa ini dapat diperbaiki oleh guru melalui pengajaran remedial, latihan, dan praktek bahasa. Ada kaitan yang erat antara pemahaman sistem linguistik siswa semakin berkurang kesalahan berbahasa dibuat oleh siswa.

\section{Kesalahan penggunaan leksikon pada penyusunan teks biografi siswa kelas X SMA Negeri 7 Medan}

Kelas yang dipilih untuk meneliti termasuk kelas yang siswanya mayoritas rajin dan termasuk kelas unggulan. Akan tetapi hal tersebut pun tidak menjadi patokan ada atau tidaknya kesalahan berbahasa yang mereka lakukan pada saat menyusun teks biografi. Masih banyak terdapat kesalahan-kesalahan berbahasa yang dilakukan oleh siswa. Seperti yang dipaparkan pada hasil penelitian, kesalahan leksikon tetap ditemukan kesalahannya, yaitu sebanyak 15 kesalahan leksikon.

Antara kesalahan berbahasa dengan pengajaran bahasa, baik pengajaran bahasa yang bersifat formal, terkait jalinan yang erat. Dimana berlangsung pengajaran bahasa sudah dapat dipastikan di situ terdapat kesalahan berbahasa.

Kesalahan berbahasa yang dibuat oleh siswa sebaiknya dikumpulkan sehingga terbentuk data kesalahan. Data kesalahan berbahasa tersebut dianalisis. Hasil penganalisisan itu sangat berfaedah sebagai umpan balik dalam menyempurnakan pengajaran bahasa. Langkah pertama yang perlu dilakukan 
terhadap data kesalahan berbahasa itu adalah memilah-milah dan berdasarkan patokannya berdasarkan patokan tertentu. Pengelompokkan kesalahan berbahasa berdasarkan patokan tertentu itu, disebut klasifikasi kesalahan berbahasa.

Dalam pengajaran bahasa, baik pengajaran bahasa pertama maupun bahasa yang dibuat oleh siswa dianggap sebagai pertanda pengajaran belum berhasil. Muncullah konsep analisis konstraktif dan analisis kesalahan berbahasa bertujuan menyempurnakan pengajaran bahasa. Baik konsep analisis konstraktif maupun analisis kesalahan berupaya untuk meminimalkan, bila dapat menghilang, kesalahan berbahasa yang dibuat oleh siswa.

Menurut Tarigan dan Sulistyaningsih (1996:126) dalam pengajaran bahasa kedua akan lebih efisien apabila diikuti empat langkah berikut.

(1) Lagkah pertama, memperbandingkan struktur bahasa ibu siswa dengan bahasa kedua dipelajari oleh siswa. Melalui perbandingan ini dapat diidentifikasikan perbedaan struktur antara bahasa ibu dan bahasa kedua.

(2) Langkah kedua, berdasarkan perbedaan struktur itu, guru dapat memprediksi kesulitan belajar dan kesalahan berbahasa yang mungkin dialami oleh siswa dalam mempelajari bahasa kedua.

(3) Langkah ketiga, kesulitan belajar dan kesalahan berbahasa yang telah diprediksi itu dijadikan sebagai landasan dalam memilih, menyusun, dan menentukan penekanan bahan pengajaran

(4) Langkah keempat, guru memilih cara-cara penyajian bahan seperti :

(i) peniruan,

(ii) pengulangan,

(iii) latihan runtun,

(iv) dan penguatan.

Pendapat umum menyatakan bahwa kesalahan berbahasa dapat bersumber pada kecerobohan atau ketidakhati-hatian pembelajar, kurangnya pengetahuan mereka, dan juga interferensi, Norrish (dalam Tarigan dan Sulistyaningsih, 1996:296) berpendapat bahwa kesalahan berbahasa bersumber pada:

a. pemilihan bahan;

b. pengajaran;

c. contoh bahasa yang digunakan sebagai bahan;

d. pembelajar. 
Bahan yang tidak sesuai dengan pembelajaran dan tidak menarik minat dapat menyebabkan terjadinya kesalahan berbahasa. Guru hendaknya menggunakan metode dan teknik mengajar dengan tepat dan menarik, juga sebaliknya memberikan contoh dan pembelajar kurang diberi rangsangan (stimulus) untuk mengembangkan aktivitas dan kreativitas dalam berbahasa. Contoh yang diberikan guru tidak sesuai atau tidak jelas. Selain hal di atas, pembelajar sendiri tidak memperhatikan penjelasan guru, kurangnya pengetahuannya, kurang berperan serta dalam proses belajar-mengajar bahasa atau barangkali guru merendahkannya. Kesalahan pembelajarnya untuk memperbaiki kesalahan berbahasanya kurang atau sama sekali tidak ada keinginan untuk memperbaiki kesalahannya.

Tarigan dan Sulistyaningsih 1996: 300 memaparkan bahwa, untuk mengatasi kesalahan bahasa tulis, kita dapat menggunakan dua macamteknik, yaitu:

a. teknik koreksi langsung (direct correction techniques)

b. teknik koreksi tidak langsung (indirect correction techniques).

Guru menggunakan teknik koreksi langsung dengan pertimbangan pembelajar kurang mampu untuk mengoreki kesalahannya, dengan demikian, guru memperbaiki kesalahan pembelajar langsung pada tulisan yang salah.

Selain itu, guru dapat juga menggunakan koreksi tidak langsung dengan pertimbangan bahwa dengan teknik ini pembelajar diberi kesempatan menginterpretasikan kode-kode (simbol) yang digunakan oleh guru pada waktu menandai kesalahan-kesalahan dari tulisan pembelajar, mereka memperbaiki kesalahan sendiri, dan kemudian menuliskan kembali karangan tersebut.

Apabila kedua teknik koreksi ini kita bandingkan, berdasarkan hasil pencobaan yang diadakan oleh Lalande (dalam Tarigan dan Sulistyaningsih, 1996) terhadap karangan para pelajar bahasa Jerman ternyata hasilnya jauh lebih baik dengan menggunakan teknik koreksi tidak langsung. Selanjutnya apakah kita akan menggunakan kedua-duanya secara bergantian sesuai dengan situasi dan kondisi pembelajar. 


\section{PENUTUP}

Berdasarkan hasil penelitian dan pembahasan yang telah diuraikan pada bab sebelumnya, dapat diperoleh tiga kesimpulan:

1. kesalahan penggunaan morfologi pada penyusunan teks biografi siswa kelas X SMA Negeri 7 Medan ditemukan 87 kesalahan (62,58\%), yang berupa afiksasi dan kata ulang. Kesalahan yang terbanyak yaitu kesalahan afiksasi sebanyak 78 kesalahan. Sementara untuk kesalahan kata ulang terdapat 9 kesalahan.

2. kesalahan penggunaan sintaksis pada penyusunan teks biografi siswa kelas X SMA Negeri 7 Medan ditemukan 37 kesalahan (26,61\%), yang berupa frasa. Kesalahan terbanyak terdapat akibat penambahan kata untuk atau yang dalam frasa nominal $(\mathrm{N}+\mathrm{V})$ yaitu sebanyak 8 kesalahan.

3. kesalahan penggunaan leksikon pada penyusunan teks biografi siswa kelas X SMA Negeri 7 Medan ditemukan 15 kesalahan (10,79\%), yang berupa kata yang tidak atau kurang tepat.

\section{SARAN}

1. Kesalahan-kesalahan dalam pembelajaran agar tidak dibiarkan berlarutlarut. Kita harus mencari sumber penyebab kesalahannya dan mencari cara bagaimana mengatasi hal tersebut.

2. Sebaiknya siswa dilatih untuk menulis atau membuat sebuah karangan sendiri, sehingga mereka tidak bergantung atau terbiasa dengan menyalin dari buku ataupun media internet. Guru harus berani memberikan tanggungg jawab kepada siswa untuk membuat atau menciptakan teks sendiri.

3. Bahan yang tidak sesuai dengan pembelajar dan tidak menarik minat dapat menyebabkan terjadinya kesalahan berbahasa. Guru hendaknya menggunakan metode dan teknik mengajar dengan tepat dan menarik, juga sebaliknya memberikan penjelasan yang sejelas-jelasnya. Jika tidak demikian dapat menimbulkan terjadinyakesalahan berbahasa. 
4. Siswa sebaiknya memperhatikan penjelasan guru, dan banyak mencari referensi-referensi dengan membaca buku, berperan serta dalam proses belajar-mengajar dan aktif dalam bertanya.

\section{DAFTAR PUSTAKA}

Arikunto. 2013. Prosedur Penelitian Suatu Pendekatan Praktik. Jakarta : Rineka Cipta

Dewi, Marsinta. 2013. Skripsi: Penerapan Metode Jigsaw II Dalam Pembelajaran Membaca Teks Biografi (Penelitian Eksperimen Semu pada Siswa Kelas XI $\begin{array}{lllll}\text { SMA Pasundan } & 2 & \text { Bandung } & \text { T.A }\end{array}$ http://repository.upi.edu/2085/4/S_IND_0907458_Chapter1.pdf. Diakses 20 Januari 2017.

Harsanti. 2014. Analisis Kesalahan Berbahasa dalam Bidang Morfologi pada Karangan Siswa Kelas VII G SMP Negeri 1 Godong. Skripsi. Universitas Muhammadiyah Surakarta. Surakarta.

Ira Wibowo. 2016. Analisis Kesalahan Ejaan dan Kalimat dalam Teks Cerita Pendek Karya Siswa Kelas IX SMP Kanisius Kalasan Sleman Tahun Ajaran 2015/2016. Skripsi.

Iskandar. 2009. Metodologi Penelitian Pendidikan dan Sosial (Kualitatif dan Kuantitatif). Jakarta : GP Press.

Mistrio. 2015. Analisis Kesalahan Penulisan Afiksasi dalam Karangan Eksposisi Siswa Kelas VII Sekolah Menengah Pertama Negeri 11 Tanjungpinang Tahun Pembelajaran 2014/2015. E-Journal. Universitas Maritim Raja Ali Haji. Tanjungpinang.

Nurul. 2012. Analisis Kesalahan Sintaksis pada Karangan Narasi Ekspositoris Siswa Kelas VIII SMP Negeri 1 Banguntapan Bantul Yogyakarta. Skripsi. Universitas Negeri Yogyakarta. Yogyakarta.

Putra, Nusa. 2013. Metode Penelitian Kualitatif Pendidikan. Jakarta: Rajawali Press.

Setyawati, Nanik. 2013. Analisis Kesalahan Berbahasa Indonesia: Teori dan Praktik. Surakarta : Yuma Pustaka 
Tarigan, Djago dan Sulistyaningsih. 1996. Analisis Kesalahan Berbahasa. Bandung: Angkasa.

Tarigan, H.G. dan Djago Tarigan. 1988. Pengajaran Analisis Kesalahan Berbahasa. Bandung: Angkasa.

Samsuri. 1982. Analisis Bahasa. Memahami Bahasa Secara Ilmiah. Malang: Erlangga. 